\title{
Pengujian Dua Pasang Primer Universal Untuk Amplifikasi Gen Cytochrome Oxidase I Copepoda
}

Thalita C. P. Sumampowa ${ }^{*}$, Beivy J. Kolondama, Feky R. Mantiria, Trina E. Talleia

aJurusan Biologi, FMIPA, Unsrat, Manado

KATA KUNCI

primer universal

Copepoda

Pandoraea sp. cytochrome oxidase I (COI)

A B S T R A K

Copepoda merupakan zooplankton kaya manfaat dengan diversitas yang sangat tinggi dan terdiri dari banyak spesies kriptik. Identifikasi cepat, akurat, dan hemat dapat dilakukan dengan menggunakan teknik DNA Barcoding. Kesuksesan teknik tersebut sangat dipengaruhi oleh penggunaan primer yang tepat. Tujuan penelitian ini adalah untuk menguji kemampuan dua pasang primer universal, yakni LC01490-HC02198 dan FF2d-FR1d, mengamplifikasi gen COI Copepoda. Dalam penelitian ini, pasangan primer LCO1490-HCO2198 tidak berhasil mengamplifikasi gen target. Sekuens-sekuens hasil amplifikasi menggunakan pasangan primer FF2d-FR1d diidentifikasi melalui BLAST. Hasil yang diperoleh menunjukan bahwa sekuens-sekuens tersebut memiliki persentase kemiripan sebesar 92\% dengan bakteri Pandoraea pnomenusa. Melalui hasil yang didapatkan disimpulkan bahwa kedua pasangan primer universal LC01490-HCO2198 dan FF2d-FR1d tidak cukup spesifik untuk amplifikasi gen cytochrome oxidase I Copepoda.

A B S T R A C T

Universal primers

Copepoda

cytochrome oxidase I (COI)

Pandoraea sp.

Copepoda is a very beneficial and highly diverse zooplankton with many cryptic species. A fast, reliable, and affordable identification can be done through DNA Barcoding. The success of this technique is affected by the usage of correct primers. The aim of this research was to test the ability of two universal primer pairs, which were LC01490-HC02198 and FF2d-FR1d, amplifying COI gene of Copepoda. In this research, LC01490HCO2198 primer pairs weren't able to amplify COI gene of Copepoda. Sequences which were successfully amplified using FF2d-FR1d primer pairs were identified through BLAST. The result shows that the sequences are $92 \%$ similar to bacteria named Pandoraea pnomenusa. It can be concluded that both primer pairs are not specific enough to amplify cytochrome oxidase I gene of Copepoda.

TERSEDIA ONLINE

10 Februari 2015

\section{Pendahuluan}

Laut menutupi $70 \%$ dari permukaan planet bumi dan vital untuk homeostasis lingkungan (Machida et al., 2009). Zooplankton adalah salah satu komponen di dalamnya yang memegang peranan penting untuk keberlangsungan sistem kehidupan ekosistem laut. Hewan ini menjadi mata rantai siklus biogeokimia di laut dan bersama fitoplankton membentuk basis rantai makanan yang dibutuhkan oleh zooplankton yang lebih besar, ikan, bahkan mamalia laut dan ikan-ikan yang bernilai ekonomi tinggi (Machida et al., 2009; NOAA, 2010; Keister et al., 2012; Lindeque et al., 2013). Ketergantungan alur rantai makanan zooplankton terhadap ketersediaan nutrisi dan perubahan cuaca dan iklim yang berpengaruh pada suhu air laut menjadikan zooplankton juga berfungsi sebagai 
bioindikator (NOAA, 2010; Radulovici et al., 2010), contohnya beberapa Rotifera, Cladocera, dan Copepoda (Ferdous dan Muktadir, 2009; Laakmann et al., 2013). Bucklin et al. (2009) memberi istilah 'rapid-responder' bagi zooplankton yang dapat berperan sebagai bioindikator.

Diversitas Copepoda dinilai sangat tinggi (Jagadeesan et al., 2009) dan terdiri dari banyak spesies kriptik (Bucklin et al., 2009; Jagadeesan et al., 2009; Laakmann et al., 2013). Hal-hal tersebut menjadikan Copepoda salah satu organisme yang penting untuk dipelajari, akan tetapi identifikasi secara morfologis hanya mungkin dilakukan oleh ahli taksonomi pada tahap Copepoda dewasa (Jagadeesan et al., 2009) dengan bagian tubuh Copepoda lengkap. Persyaratan dalam identifikasi tersebut dapat menghambat proses pembelajaran bahkan pemantauan Copepoda di ekosistem (Lindeque et al., 2013).

Salah satu upaya yang dapat dijadikan solusi adalah teknik identifikasi DNA Barcoding. Pengaplikasian teknik DNA Barcoding sangat membantu karena metode identifikasi konvensional memerlukan waktu yang relatif lama dan identifikasi morfologi terhadap spesies tertentu hampir tidak mungkin dilakukan (Li et al., 2011). Gen cytochrome oxidase I (COI) merupakan salah satu region target dalam teknik DNA Barcoding karena dinilai efektif untuk digunakan sebagai diskriminan kelompok hewan (Costa et al., 2007).

Kesuksesan gen COI sebagai kode batang untuk dipakai dalam mengidentifikasi spesies tidak lepas dari keberhasilan amplifikasi gen tersebut dalam polymerase chain reaction atau PCR yang ditentukan oleh pasangan primer yang digunakan. Observasi dan konstruksi primer universal dilakukan dengan tujuan standarisasi dan meningkatkan keakuratan sekuens yang diperoleh (Chase et al., 2007). Salah satu urgensi mengenai hal tersebut adalah bahwa penerapan DNA Barcoding pada organisme yang hidup di laut lebih sulit dilaksanakan ditinjau dari diversitas yang tinggi, namun primer dengan efisiensi konstan tidak cukup tersedia (Lobo et al., 2013). Walaupun primer yang dianggap universal seringkali berhasil mengamplifikasi banyak kelompok hewan, akan tetapi primer-primer tersebut gagal mengamplifikasi COI berbagai kelompok hewan maritim. Siddall et al. (2007) memperlihatkan bahwa pasangan primer universal LCO1490-HCO2198 (Folmer et al., 1994) gagal mengamplifikasi DNA sampel Moluska tetapi berhasil mengamplifikasi bakteri gammaprotebacteria dan beberapa bakteri lainnya. Hal ini mengakibatkan universalitas suatu primer dinilai menjadi salah satu keterbatasan teknologi DNA Barcoding (Radulovici et al., 2010).

Primer lain yang dinilai memiliki universalitas tinggi untuk mengamplifikasi gen $\mathrm{COI}$ hewan akuatik adalah FF2d dan FR1d (Ivanova et al., 2007). Pasangan primer ini berhasil ketika digunakan untuk identifikasi ikan hias (Steinke et al., 2009), identifikasi komunitas ikan terumbu karang (Hubert et al., 2011), dan klarifikasi kesalahan penamaan pada ikan-ikan komersil (Filonzi et al., 2010).

Berdasarkan tinjauan terhadap pentingnya penyempurnaan metode DNA Barcoding Copepoda agar mampu menghasilkan informasi akurat sebagai alat identifikasi, maka pengujian terhadap dua pasang primer universal yaitu LCO1490HCO2198 dan FF2d-FR1d untuk amplifikasi gen COI Copepoda perlu dilakukan.

\section{2. $\quad$ Metode}

\subsection{Waktu dan Tempat}

Penelitian ini dilaksanakan pada bulan September sampai Oktober 2014. Sampel Copepoda diambil di perairan pulau Bunaken. Penelitian di laboratorium dilaksanakan di Laboratorium Bioteknologi, Jurusan Biologi, Fakultas Matematika dan IImu Pengetahuan Alam Universitas Sam Ratulangi.

\subsection{Metode Pengambilan Sampel dan Pengamatan Morfologi Copepoda}

Sampel Copepoda diambil dengan teknik horizontal sampling menggunakan plankton net pada kolom air dengan kedalaman $15-30 \mathrm{~cm}$ kemudian dimasukan di dalam botol-botol sampel yang berisi alkohol 95\%. Sampel Copepoda yang diperoleh diidentifikasi secara morfologis menggunakan mikroskop binokuler. Karakteristik morfologi setiap Copepoda didokumentasi untuk komparasi dan dicocokan dengan gambar asli maupun sketsa yang telah dipublikasikan.

\subsection{Ekstraksi dan Amplifikasi DNA}

Seluruh bagian organisme digunakan dalam tahapan ini untuk mendapatkan ekstrak DNA total dengan menggunakan Multisource Genomic DNA Miniprep Kit (Axygen). Kit ini memanfaatkan teknik purifikasi kolom yang mampu mengekstrak DNA total sel yang terdiri dari DNA inti dan mitokondria. Gen COI diamplifikasi menggunakan dua pasang primer, yakni FF2d (5'-TTC TCC ACC AAC CAC AAR GAY ATY GG-3') sebagai primer forward dan FR1d (5'-CAC CTC AGG GTG TCC GAA RAA YCA RAA-3') sebagai primer reverse (Ivanova et al., 2007) dan LC01490 (5'-GGT CAA CAA ATC ATA AAG ATA TTG G3') dan sebagai primer forward dan HCO2198 (5'TAA ACT TCA GGG TGA CCA AAA AAT CA-3') sebagai primer reverse (Folmer et al., 1994). Kit untuk PCR yang digunakan adalah 5X Ready-to-Load Master Mix (Solis Biodyne) yang komposisinya terdiri atas Taq DNA polimerase, Taq Buffer, dNTPs mix, $\mathrm{MgCl}_{2}$ dan loading dye. Pengaturan suhu untuk mesin PCR dimulai dengan denaturasi awal selama 2 menit pada $95^{\circ} \mathrm{C}$, dilanjutkan dengan 35 siklus tahap denaturasi $\left(94^{\circ} \mathrm{C}\right.$ selama 30 detik), perlekatan primer atau fase annealing $\left(47^{\circ} \mathrm{C}\right.$ selama 30 detik) dan ekstensi DNA $\left(72^{\circ} \mathrm{C}\right.$ selama 1 menit) (Pegg et al., 2006). 


\subsection{Elektroforesis DNA}

Gel agarosa yang digunakan berkonsentrasi $0,8 \%$. DNA yang terdapat pada gel agarosa akan divisualisasi dengan sinar UV menggunakan UVTransiluminator. Hasil yang tampak didokumentasi menggunakan kamera digital dan filter sinar UV.

\subsection{Waktu dan Tempat}

Kromatogram DNA yang dihasilkan dari proses sekuensing disunting menggunakan perangkat lunak Geneious v5.6. Proses reverse and complement dilakukan pada kromatogram sekuens yang menggunakan primer reverse, kemudian dengan program MUSCLE (Edgar, 2004) yang terintegrasi dalam Geneious v5.6 kromatogram tersebut dipadukan dengan kromatogram sekuens yang menggunakan primer forward. Potongan gen COI masing-masing sampel dalam format FASTA diidentifikasi lewat BLAST pada situs basis data nukleotida GenBank (www.ncbi.nlm.nih.gov).

\section{Hasil dan Pembahasan}

Hasil pengamatan morfologi Copepoda menunjukan bahwa ketiga sampel berasal dari Ordo Calanoida. Morfologi kedua sampel dapat dilihat pada Gambar 1. Penentuan ordo didasari pada pengamatan morfologi dengan melihat ciri-ciri utama ordo Calanoida menurut Bradford-Grieve (2002), yakni perbedaan lebar prosom dan urosom yang signifikan dan artikulasi yang ditemukan di antara pedigerous ke-5 ( $\mathrm{Pd} 5)$ dan genital somite (membentuk posisi gymnoplean). Somite pada jantan berjumlah empat sedangkan pada betina berjumlah 5 dan terdapat sepasang caudal rami di ujung urosom. Jenis kelamin seluruh sampel tidak dapat ditentukan oleh karena karakteristik lainnya tidak dapat diamati. Karakteristik lain ordo Calanoida menurut IMAS (2013) yang berhasil diamati adalah panjang antena sama dengan dan atau melebihi panjang tubuh.

Pasangan primer LC01490-HCO2198 gagal mengamplifkasi gen COI sampel, sedangkan pasangan primer FF2d-FR1d dengan suhu perlekatan $47^{\circ} \mathrm{C}$ berhasil mengamplifikasi 2 dari 3 sampel DNA dalam penelitian ini yaitu DNA sampel 1 dan sampel 3. DNA yang sukses diamplifikasi ditunjukkan oleh munculnya pita pada gel agarosa hasil elektroforesis (Gambar 2). Panjang fragmen DNA yang diperoleh sesuai dengan perkiraan yakni 700 bp. DNA sampel 2 tidak berhasil diamplifikasi dikarenakan konsentrasi tidak memadai.

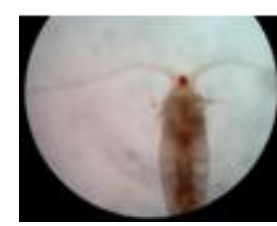

a

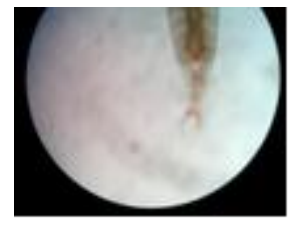

b

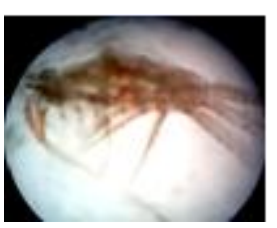

C

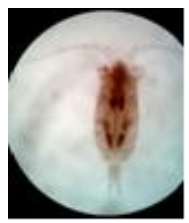

d

Gambar 1. Morfologi Sampel Calanoida. A) Bagian Prosom Sampel 1, B) Bagian Prosom (Pd 2 - Pd 5) dan Urosom Sampel 1, C) Sampel 2, D) Sampel 3.

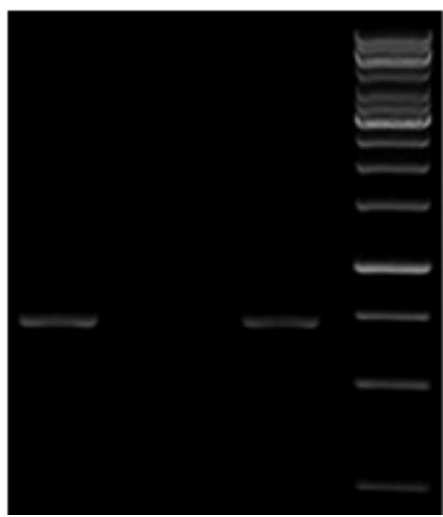

Gambar 2. Visualisasi Produk PCR melalui Elektroforesis Gel Agarosa 0,8\% [Keterangan: 1 = Sampel Copepoda 1, 2 = Sampel Copepoda 2, $3=$ Sampel Copepoda 3]

Sekuens dalam bentuk kromatogram yang diperoleh setelah proses sekuensing berkualitas baik dengan kisaran nilai HQ\% 82,8-87,1\%. Deskripsi mengenai sekuens DNA sampel dapat dilihat pada Tabel 1.
Setelah proses penyuntingan sekuens fragmen DNA yang diperoleh dari kedua sampel saling disejajarkan. Dari proses tersebut diperlihatkan kedua sekuens memiliki kemiripan 100\% dan setelah sekuens diubah ke dalam bentuk FASTA untuk dibandingkan dengan sekuens lainnya menggunakan metode BLAST, diketahui bahwa sekuens sampel memiliki persentase kemiripan 92\% dengan Pandoraea sp. yang merupakan bakteri dari Filum Proteobacteria. Hal ini menunjukan kontaminasi pada sampel. Kontaminan bisa berasal baik dari DNA beberapa sampel yang bercampur pada reagen maupun dari manusia, bakteri, dan organisme lainnya.

Ketepatan amplifikasi sangat bergantung kepada spesifitas primer yang digunakan. Semakin spesifik sebuah primer semakin tinggi tingkat keakuratan sekuens yang bisa diperoleh. Demikian pula sebaliknya, yaitu semakin 'universal' sebuah primer semakin banyak kemungkinan fragmen gen yang dapat diamplifikasi. Contohnya adalah pasangan primer LC01490-HCO2198 (Folmer et al., 1994) yang dinilai cukup tinggi ketika digunakan untuk amplifikasi invertebrata akuatik, termasuk 
Copepoda, (Bucklin et al., 2009), namun pada penelitian yang dilakukan Siddall et al. (2009) amplifikasi sampel DNA yang diambil dari Moluska menghasilkan sekuens bakteri yang termasuk dalam Kelas Gammaproteobacteria. Dalam penelitian ini pasangan primer yang berhasil digunakan untuk amplifikasi gen COI sampel adalah FF2d-FR1d (Ivanova et al., 2007). Pasangan primer ini sebelumnya sukses mengamplifikasi berbagai spesies ikan (Ivanova et al., 2007; Steinke et al., 2009; Filonzi et al., 2010), akan tetapi tidak cukup spesifik untuk mengamplifikasi gen COI Copepoda, khususnya Ordo Calanoida.

Tabel 1. Deskripsi Hasil Sekuensing Kode Batang COI

\begin{tabular}{|c|c|c|c|c|c|c|}
\hline No. & $\begin{array}{c}\text { Sampel } \\
\text { Copepoda }\end{array}$ & $\begin{array}{c}\text { Gen } \\
\text { Kode } \\
\text { Batang }\end{array}$ & Primer & HQ\% & $\begin{array}{c}\text { Panjang } \\
\text { Sekuens } \\
\text { Tersunting }\end{array}$ & $\begin{array}{c}\text { Panjang } \\
\text { Sekuens } \\
\text { Gabungan } \\
\end{array}$ \\
\hline \multirow{2}{*}{1.} & \multirow{2}{*}{1} & \multirow{2}{*}{ COI } & FF & $85,6 \%$ & $680 \mathrm{bp}$ & \multirow{2}{*}{712 bp } \\
\hline & & & FR & $87,1 \%$ & $672 b p$ & \\
\hline \multirow{2}{*}{2.} & \multirow[t]{2}{*}{3} & \multirow{2}{*}{ COI } & FF & $82,8 \%$ & $688 \mathrm{bp}$ & \multirow{2}{*}{722 bp } \\
\hline & & & FR & $85,9 \%$ & $675 \mathrm{bp}$ & \\
\hline
\end{tabular}

Untuk melihat kekerabatan dengan bakteribakteri yang memiliki tingkat kemiripan tinggi berdasarkan hasil BLAST, disusun sebuah pohon filogenetik (Gambar 3) menggunakan metode Neighbor-Joining (Satou dan Nei, 1987) dengan model jarak Tamura-Nei (Tamura dan Nei, 1993). Pohon filogenetik yang disusun menunjukan bahwa gen $\mathrm{COl}$ cukup variatif untuk digunakan sebagai pembeda interspesies dan berdasarkan gen COI bakteri sampel merupakan anggota Genus Pandoraea.

Kontaminasi oleh bakteri pada sampel Copepoda bersumber dari asosiasi bakteri dan Copepoda. Menurut Brandt (2010) dan Jing et al. (2012), kelas Alphaproteobacteria dan Gammaproteobacteria dari Filum Proteobacteria mendominasi jenis bakteri yang ditemukan berasosiasi dengan berbagai genus Copepoda. Dalam penelitian ini, bakteri yang ditemukan, yakni Genus Pandoraea, termasuk dalam Kelas Betaproteobacteria, Ordo Burkholderiales, Famili Burkholderiaceae (Coenye et al., 2000), yang juga ditemukan pada saluran pernapasan penderita cystic fibrosis (Fera et al., 2007). Pandoraea sp. yang diidentifikasi dari sampel Copepoda Genus Calanoida mengindikasikan adanya kandungan bakteri patogen di perairan Pulau Bunaken, khususnya daerah tempat pengambilan sampel. Tingginya tingkat paparan terhadap aktivitas manusia, sampah, dan materi organik terlarut yang terbawa di area tersebut sangat mempengaruhi diversitas dan kelimpahan organisme yang hidup di dalamnya.

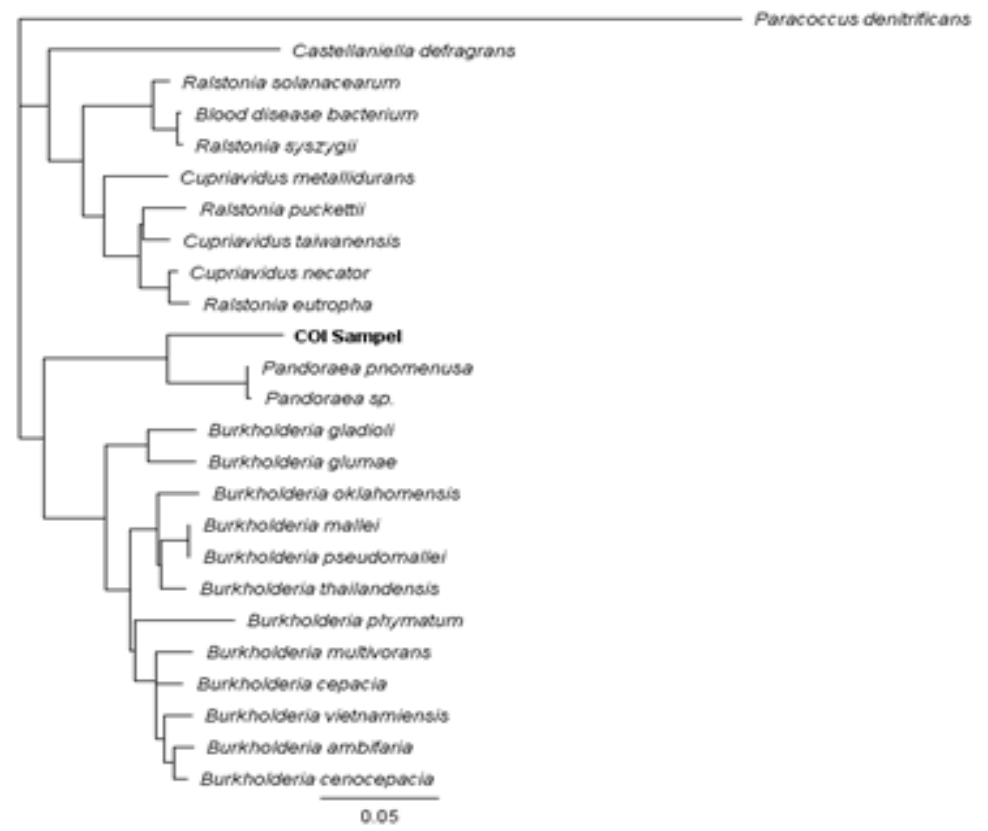

Gambar 3. Pohon Filogenetik Neighbor-Joining dari Sekuens COI Sampel dan Beberapa Kerabat Terdekatnya 


\section{Kesimpulan}

Berdasarkan hasil dan pembahasan disimpulkan bahwa pasangan primer FF2d-FR1d dan LC01490-HCO2198 tidak cukup spesifik untuk amplifikasi gen COI Copepoda sampel.

\section{Daftar Pustaka}

Bradford-Grieve, J. M. 2002. Key to Calanoid Copepod Families. www.crustacea.net. [22 Oktober 2014].

Brandt, P. 2010. The Bacterial Community of Marine Copepods [disertasi]. School of Engineering and Science Alfred Wegener Institute for Polar and Marine Research, Helgoland.

Bucklin, A., R. R. Hopcroft, K. N. Kosobokova, L. M. Nigro, B. D. Ortman, R. M. Jennings, dan C. J. Sweetman. 2009. DNA Barcoding of Arctic Ocean Holozooplankton for Species Identification and Recognition. Deep-Sea Research II. doi:10.1016/j.dsr2.2009.08.005.

Chase, M. W., R. S. Cowan, P. M. Hollingsworth, et al. 2007. A Proposal for A Standardised Protocol to Barcode All Land Plants. Taxon. 56(2): 295-299.

Coenye, T., E. Falsen, B. Hoste, M. Ohlen, J. Goris, J. R. W. Govan, M. Gillis dan P. Vandamme. 2000. Description of Pandoraea gen. nov. with Pandoraea apista sp. nov., Pandoraea pulmonicola sp. nov., Pandoraea fpnomenusa sp. nov., Pandoraea sputorum sp. nov. and Pandoraea norimbergensis comb. nov. Int. J. Syst. Evol. Microbiol. 50: 887-899.

Costa, F. O., J. R. deWaard, J. Boutillier, S. Ratnasingham, R. T. Dooh, M. Hajibabei, P. D. N. Hebert. 2007. Biological Identifications through DNA Barcodes: The Case of Crustacea. Canadian J. Fish. \& Aqua. Sci. 64(2): 272-295. doi: 10.1139/f07-008.

Edgar, R. 2004. MUSCLE: Multiple Sequence Alignment with High Accuracy and High Throughput. Nucleic Acid Research. 32(5): 17921797.

Fera, M. T., T. L. Maugeri, C. Gugliandolo, D. Bonanno, E. La Camera, S. Papasergi, dan M. Carbone. 2007. Occurrence of Burkholderia cepacia complex, Ralstonia and Pandoraea species DNAs in the coastal environment of the Straits of Messina (Italy). Mar. Pol. Bul. 54: 792819. doi:10.1016/j.marpolbul.2007.01.019.

Ferdous, Z. dan A. K. M. Muktadir. 2009. A Review: Potentiality of Zooplankton as Bioindicator. American J. App. Sci. 6(10): 1815-1819. doi: 10.3844/ajassp.2009.1815.1819.

Filonzi, L., S. Chiesa, M. Vaghi, dan F. N. Marzano. 2010. Molecular Barcoding Reveals Mislabelling of Commercial Fish Products in Italy. Food Res. Int. 43: 1383-1388.

Folmer, O., M. Black, W. Hoeh, R. Lutz, R. Vrijenhoek. 1994. DNA Primers for Amplification of
Mitochondrial Cytochrome C Oxidase Subunit I from Diverse Metazoan Invertebrates. Mol. Mar. Bio. Biotech. 3: 294-299.

Hubert, N., E. Paradis, H. Bruggemann, dan S. Planes. 2011. Community Assembly and Diversification in Indo-Pacific Coral Reef Fishes. Ecol. Evol. 1(3): 229-277. doi: 10.1002/ece3.19

Institute for Marine and Antarctic Studies (IMAS). 2013. Copepoda. www.imas.utas.edu.au. [22 Oktober 2014].

Ivanova, N. V., T. S. Zemlak, R. H. Hanner, dan P. D. N. Hebert. 2007. Universal Primer Cocktails for Fish DNA Barcoding. Mol Ecol Notes. 7:544-548.

Jagadeesan, L., P. Perumal, dan M. Thangaraj. 2009. Molecular Identification of Marine Calanoid Copepod Paracalanus parvus (Claus 1863) Using RFLP. World J. Fish \& Marine Sci. 1 (3): 239-242.

Jing, H., L. Shek, W. Yung, X. Jin, dan H. Liu. Dyna. Dynamics of Bacterial Community Composition During Degradation of Copepod Fecal Pellets. J. Plankt. Res. doi: 10.1093/plankt/fbs043.

Keister, J. E., D. Bonnet, S. Chiba, C. L. Johnson, dan D. L. Mackas. 2012. Zooplankton population connections, community dynamics, and climate variability. ICES J. Mar. Sci. 69: 347-350.

Kolondam, B. 2012. Barcoding DNA rbcL dan matK Aglaonema (Aglaonema sp.). Anthurium Gelombang Cinta (Anthurium plowmanii) dan Anggrek Payus Limondok (Phaius tancarvilleae) [tesis]. FMIPA UNSRAT, Manado.

Laakmann, S., G. Gerdts, R. Erler, T. Knebelserger, P. M. Arbizu, dan M.J. Raupach. 2013. Comparison of Molecular Species Identification for North Sea Calanoid Copepods (Crustacea) Using Proteome Fingerprints and DNA Sequences. Mol. Eco. Res. doi: 10.1111/1755-0998.12139.

Li, C., M. Wang, F. Cheng, dan S. Sun. 2011. DNA Barcoding and Its Application to Marine Zooplankton Ecology. Biodiv. Sci. 19(06): 805814. doi: 10.3724/SP.J.1003.2011.10173.

Lindeque, P. K., H. E. Parry, R. A. Harmer, P. J. Somerfield, dan A. Atkinson. 2013. Next Generation Sequencing Reveals the Hidden Diversity of Zooplankton Assemblages. PLoS ONE. 8(11): doi:10.1371/journal.pone.0081327.

Lobo, J., P. M. Costa, M. A. L. Teixeira, M. S. G. Ferreira, M. H. Costa, dan F. O. Costa. 2013. Enhanced Primers for Amplification of DNA Barcodes from A Broad Range of Marine Metazoans. BMC Ecology. 13:34.

Machida, R. J., Y. Hashiguchi, M. Nishida, dan S. Nishida. 2009. Zooplankton Diversity Analysis Through Single-gene Sequencing of a Community Sample. BMC Genomics. 10:438. doi: 10.1186/1471-2164-10-438.

NOAA, 2010. PLANKTON: Why Are They Important?. www.st.nmfs.noaa.gov. [29 Juli 2014] 
Pegg, G. G., B. Sinclair, L. Briskey, dan W. J. Aspden. 2006. MtDNA Barcode Identification of Fish. Scientia Marina. Hal. 7-12.

Radulovici, A. E., P. Archambault, dan F. Dufresne. 2010. DNA Barcodes for Marine Biodiversity: Moving Fast Forward?. Diversity. 2: 450-472. doi: 10.3390/d2040450.

Saitou, N. dan M. Nei. 1987. The Neighbour-Joining Method: A New Method for Reconstructing Phylogenetic Trees. Mol. Biol. Evol. 4(4): 406425.

Siddall, M. E., F. M. Fontanella, S. C. Watson, S. Kvist, dan C. Ers'eus. 2009. Barcoding
Bamboozled by Bacteria: Convergence to Metazoan Mitochondrial Primer Targets by Marine Microbes. Syst. Biol. 58(4): 445-451.

Steinke D., T. S. Zemlak, P. D. N. Hebert. 2009. Barcoding Nemo: DNA-Based Identifications for the Ornamental Fish Trade. PLoS ONE. 4(7): e6300. doi:10.1371/journal.pone.0006300

Tamura, K. dan M. Nei. 1993. Estimation of The Number of Nucleotide Substitutions in The Control Region of Mitochondrial DNA in Humans and Chimpanzees. Mol. Biol. Evol. 10(3): 512526. 